UDC 537.874

PACS 77.22. $-\mathrm{d}$

\author{
S. V. Nedukh ${ }^{1,2}$, S. Y. Polevoy ${ }^{1}$, S. I. Tarapov ${ }^{1,2,3}$, A. S. Vakula ${ }^{1,3}$ \\ ${ }^{1}$ O. Ya. Usikov Institute for Radiophysics and Electronics of NAS of Ukraine \\ 12, Acad. Proskury St., Kharkiv, 61085, Ukraine \\ ${ }^{2} \mathrm{~V}$. Karazin National University of Kharkov \\ 4, Svoboda Sq., Kharkiv, 61022, Ukraine \\ ${ }^{3}$ Kharkiv National University of Radio Electronics \\ 14, Nauka Av., Kharkiv, 61166, Ukraine \\ E-mail: polevoy@ire.kharkov.ua
}

\title{
IDENTIFICATION OF LIQUIDS IN DIFFERENT CONTAINERS A USING MICROWAVE PLANAR METAMATERIAL
}

\begin{abstract}
At present, the fast contactless identification of liquids enclosed into a container has a practical importance. The identification of liquids can be required, for example, at airports, in order to prevent the transport of illicit liquids in bottles. However, the complexity of applying contactless methods lies in the difficulties to take into account the influence of container characteristics. In this paper, a metamaterial based on two planar photonic crystals (PPC) has been applied for the experimental analysis of liquids in different containers. It was shown experimentally how the transmission coefficient spectrum of PPC varied with changing the characteristics of a container with a liquid. Namely, the influence of thickness and material of the container walls and the inclination angle of its axis relative to the metamaterial plane on the transmission coefficient has been studied. The reliable differing of concentration increments of edible salt and sugar in water was determined as $10 \%$. It is shown that an increase of the container walls thickness leads to a decrease of the reliability of the liquid identification in it. Thus, the influence of some container characteristics on the reliability of contactless identification of liquids by using PPC has been taken into account. Fig.: 6. Ref.: 6 titles.

Key words: metamaterial, photonic crystal, identification, microwaves.
\end{abstract}

Today, the fast contactless identification of liquids enclosed into a container is an actual task for safety systems and quality control of products. It can be applied, for example, at airports for filtering illicit liquids in bottles. Thus prototypes of devices for identification of liquids based on small perturbation theory [1] are known now. One of these devices was successfully implemented in practice [2], where the cylindrically shaped dielectric resonator was applied at frequencies less than $2 \mathrm{GHz}$ for this purpose. But the device designed using this idea has relatively large size and complexity of construction. This prevents its introduction everywhere. A prospective alternative to this design is a metamaterial based on planar photonic crystals (PPC) [3-5]. It possesses the simplicity of fabrication, low cost, quite small dimensions, while maintaining sensitivity to the liquids identification. A distinctive feature is that the device based on PPC can be designed as a pocket size version. To realize it the operating frequency of the PPC should be of about $10 \mathrm{GHz}$. However, at this frequency it is necessary to take into account the parameters of the container where the liquid is placed. Therefore, the aim of this work is to find the influence of the container walls (both their material and thickness) and the inclination angle of container axis relative to the metamaterial plane on the reliability of contactless identification of liquids.

1. Experimental technique. As it was shown earlier [3-5], the metamaterial formed by two serially connected planar photonic crystals with some certain parameters possess a set of passbands and stopbands in the spectrum of transmission coefficient. The narrow resonance transmission peak, identified as electrodynamic analog of known "Tamm state", appears in one of stopbands of the transmittance spectrum of the metamaterial. For the formation of this peak the effective impedances of the two photonic crystals at a certain frequency must be equal, and this frequency must belong to the stopbands of both photonic crystals. At the frequency of the peak the electromagnetic energy concentration occurs in the vicinity of the interface of two photonic crystals [3]. The resonance field is partially illuminated to the ambient space.

The experimental setup for the liquids identification using PPC metamaterial is shown in Fig. 1 [5]. It consists of the metamaterial in microstrip design, fitted to the Vector network analyzer N5230A for measuring the transmission coefficient of electromagnetic waves in the frequency range $9-10 \mathrm{GHz}$. To improve the accuracy of measurements [6], a two-coordinate scanning module has been applied. This scanner allowed to make precise positioning of the measured liquid enclosed into the container relative to the interface of two PPC.

The parameters of the resonance peak are determined on the basis of the measured frequency dependence of the transmission coefficient as follows. At first, the least-squares method of approximation of the transmission coefficient $T$ 
spectrum by Lorenz curve shape is carried out. This spectrum is described by the formula:

$$
T=c+\frac{a}{1+b\left(f-f_{\text {res }}\right)^{2}},
$$

where $a, b, c, f_{\text {res }}$ are adjustable parameters. These parameters of the resonance peak are determined using the approximation dependence (1). Namely, we can determine the resonant frequency $f_{\text {res }}$ and the $Q$-factor as $Q=f_{\text {res }} \sqrt{b(1+\sqrt{2})} / 2$. Here we determine the linewidth on the height-level $I_{\max } / \sqrt{2}$.

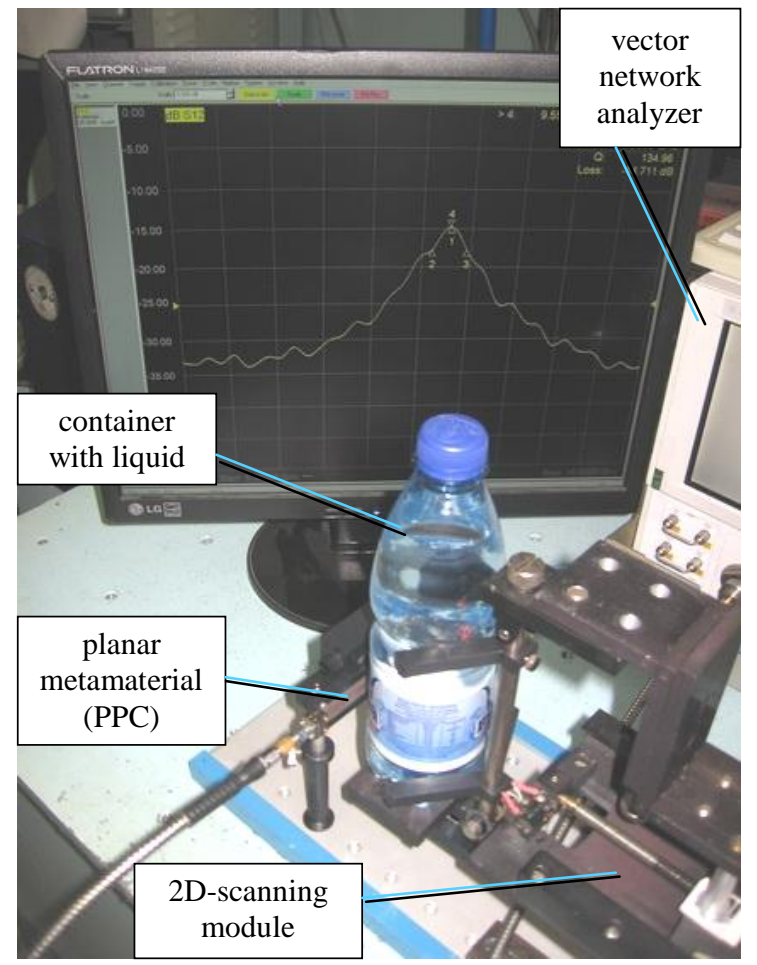

Fig. 1. The photo of the experimental setup

2. Experiment and data analysis. During the experiment the resonance frequency $f_{\text {res }}$ of the peak and the inverse quality factor $1 / Q$ are determined [5]. It was shown experimentally that when the liquid in container is placed into the resonance area at the interface of two PPCs the parameters of resonance peak start to vary. For some fixed distance $\delta h_{\text {var }}$ from the interface of the PPCs to the container with the liquid, we have only one point on the graph with coordinates of $f_{\text {res }}$ and $1 / Q$ [2] (Fig. 2). When this distance $\delta h_{\mathrm{var}}$ is changed, we obtain a set of these parameters $\left(f_{\text {res }}\right.$ and $\left.1 / Q\right)$. It is suitable to present them as some certain curve on the graph (Fig. 2). Certainly, we can measure the parameters $1 / Q$ и $f_{\text {res }}$ at one optimal value of $\delta h_{\mathrm{var}}$. However, the curves obtained for the set of $\delta h_{\mathrm{var}}$ increase the reliability of the liquid identifying.

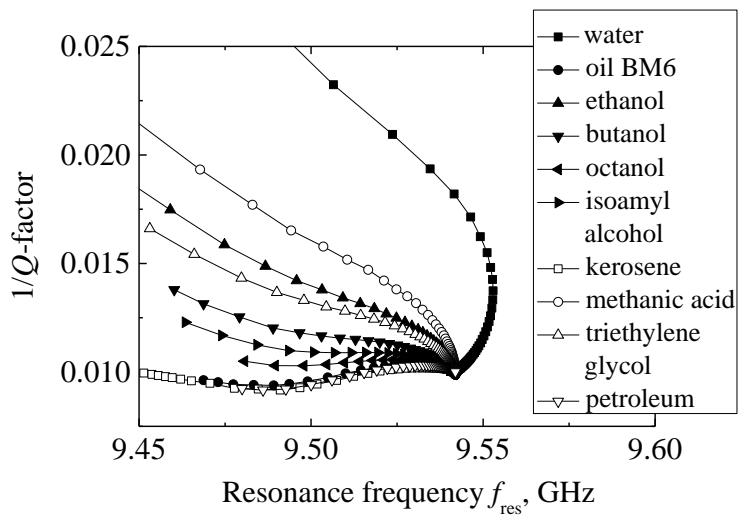

Fig. 2. The inverse $Q$-factor and the resonance frequency for various distances between the interface of the photonic crystals to the thin plastic container with different liquids

The different character of dependence of $1 / Q$ and $f_{\text {res }}$ on the distance $\delta h_{\text {var }}$ for different liquids in a thin polystyrene container at room temperature was shown experimentally (Fig. 2). Note that large losses in the liquid lead to a decrease of peak $Q$-factor, and the above-described curve is shifted up. Thus, rapid express analysis of the liquid may consist in the selection of such previously measured curve for the known liquid which most closely approaches the measured unknown liquid, which leads to its identification [5].

The influence of the wall thickness of the container with water on the shape of the dependence $1 / Q$ and $f_{\text {res }}$ on the distance $\delta h_{\text {var }}$ is given on Fig. 3.

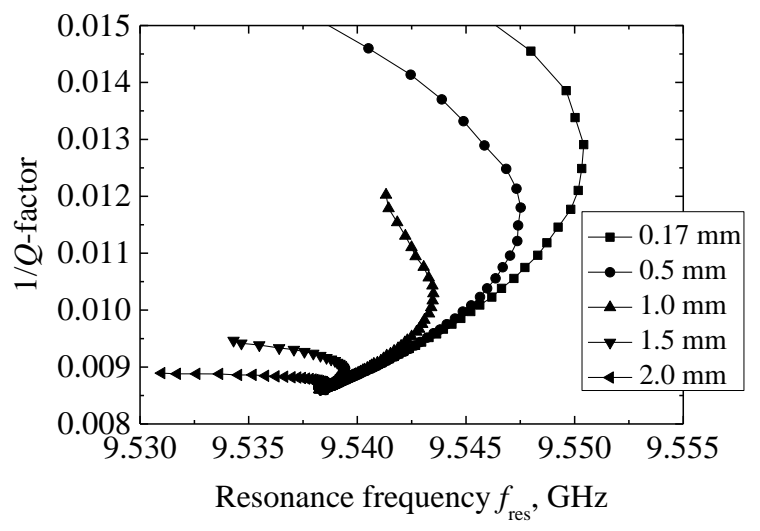

Fig. 3. The inverse $Q$-factor and the resonance frequency for various distances from the interface of the photonic crystals to the container with water and different container wall thicknesses

The polystyrene cups are used as containers, which, if necessary, were inserted one into another. Thus, the increase of the container walls thickness was simulated. It was found that the thickness of the container walls with the liquid has a great impact on the shape of the dependence of the inverse $Q$-factor and the resonance frequency on the distance $\delta h_{\mathrm{var}}$. Starting at a thickness of $1.0 \mathrm{~mm}$, a decrease in the sensitivity of the setup to the container content is 
observed by reason of a small depth of the field penetration (Fig. 3).

The influence of the edible salt concentration in water on the shape of the dependence $1 / Q$ and $f_{\text {res }}$ on the distance $\delta h_{\text {var }}$ (Fig. 4, a) was investigated in a thin polystyrene container at room temperature.

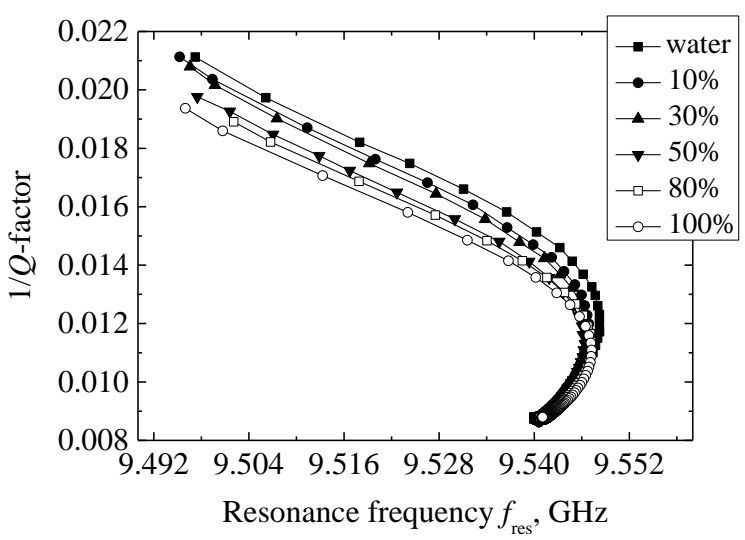

a)

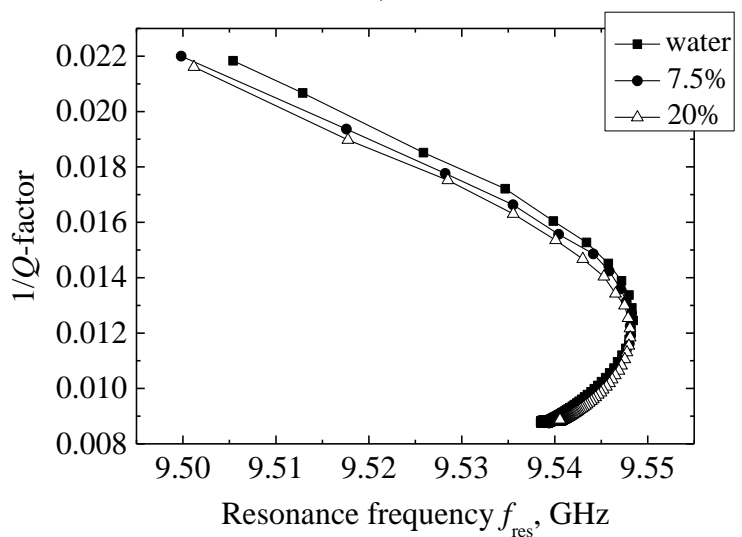

b)

Fig. 4. The inverse $Q$-factor and the resonance frequency for various distances from the interface of the photonic crystals to the container with liquids: a) for various concentrations of edible salt in water (relative to the saturated solution concentration); b) for various concentrations of sugar in water

In Fig. 4, a the mass concentration of salt in a saturated solution is assumed as $100 \%$. An increase in salt concentration leads to a decrease of the $1 / Q$ parameter. It can be seen that the dependences are clearly distinguishable when the salt concentration in water changes by about $10 \%$ relative to the saturated solution concentration. The influence of sugar mass concentration in water on the shape of the same dependence is shown in Fig. 4, b. An obvious difference in the dependence of $1 / Q$ and $f_{\text {res }}$ on the distance $\delta h_{\text {var }}$ can be obtained by changing the sugar concentration in water by more than $7.5 \%$.

The influence of the material of various plastic containers with water on the shape of the dependence of the inverse $Q$-factor and the resonant frequency of the peak on the distance of $\delta h_{\mathrm{var}}$ was investigated (Fig. 5). Note that the high pressure polyethylene (PEHD) container had a wall thickness greater than a series of polyethylene terephthalate containers (PETbottles) that were approximately equal in thickness. It can be seen that PET-containers have the similar shapes of dependence $1 / Q$ and $f_{\text {res }}$ on the distance $\delta h_{\mathrm{var}}$, and numerical differences can be explained by small differences in the form of the container walls. For example, the similar variations in the shape of dependences give an increase in the alcohol concentration in water of about 5-10\% [5]. At our frequency of the peak, the thickness of the container walls and its material have a significant effect on the shape of the dependences. It can be seen from the curve for the PEHD container (Fig. 5), which is significantly different from the curves for PET containers. This confirms the measurement results of one liquid in containers with different wall thicknesses (Fig. 3). In this case, the similar changes in the curves can give an increase in the alcohol concentration in water of about 30-40\% [5].

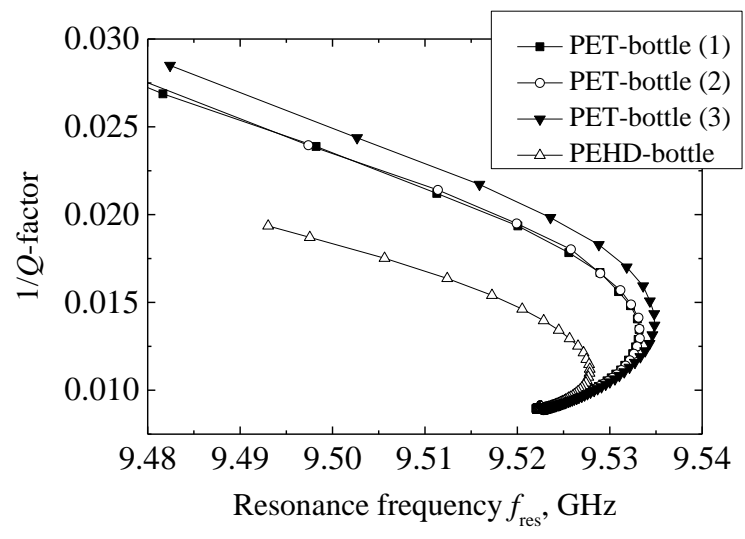

Fig. 5. The inverse $Q$-factor and the resonance frequency for various distances from the interface of the photonic crystals to the different plastic containers with water

In addition, the influence of the vertical slope of the container with water on the shape of the dependence of the inverse $Q$-factor and the resonance frequency on the distance $\delta h_{\mathrm{var}}$ for two cases was investigated (Fig. 6). In the first case, the slope of the symmetry axis of the PET container was in the plane normal to the metamaterial plane (Fig. 6, a). In the second case, the slope of the symmetry axis of the PET container was in the plane parallel to the metamaterial plane (Fig. 6, b).

In both cases, as the inclination angle of the container increases, the resonant frequency $f_{\text {res }}$ shifts on higher frequencies by the value of about $6 \cdot 10^{-3} \%$ per $1^{\circ}$ of the inclination for the first case, and by the value of about $3 \cdot 10^{-3} \%$ per $1^{\circ}$ for the second one. Note that these resonance frequency 
shifts are insignificant and do not affect the reliability of the liquid identification. However, the changes in the thickness of the container walls introduce a much greater error (Fig. 3), which may affect the reliability of the liquid identification.

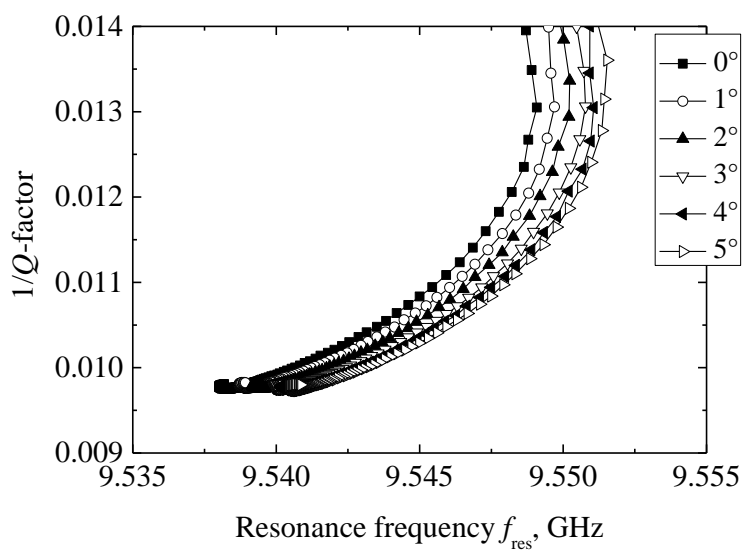

a)

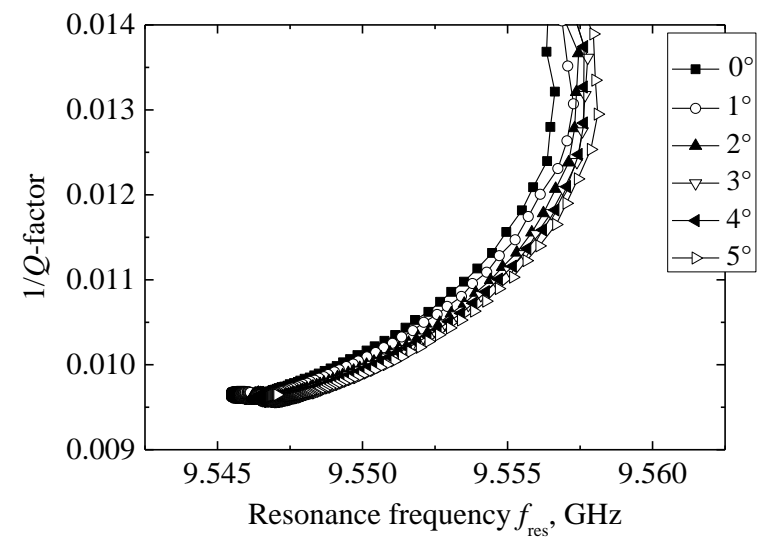

b)

Fig. 6. The inverse $Q$-factor and the resonance frequency for various distances from the interface of the photonic crystals to the container with water and for different values of the vertical inclination angle of the symmetry axis of the PET container in the plane: a) normal to the metamaterial plane; b) parallel to the metamaterial plane

Conclusions. In this work we have applied the technique of liquids identification using a metamaterial based on two planar photonic crystals at frequency of about $9.5 \mathrm{GHz}$ for various types of containers. The possibility to find differences (to make identification) for various liquids in containers with comparable wall thicknesses and fabricated from the same material has been shown experimentally.

It has been demonstrated that the reliability of the determination of concentration increments for edible salt and sugar in water is better than $10 \%$. It is shown that the thickness of the container walls leads to the sufficient error in liquids identification. Thus, in contactless identification of liquids, some characteristics of the container must be taken into account.
Some results of the work can be used for researches in the framework by NATO Science for Peace and Security Program, NATO SPS project No. 985005 (G5005).

The authors are grateful to the staff of the Biological Physics department of the Institute for radiophysics and electronics of NAS of Ukraine for providing the samples for the research.

\section{REFERENCES}

1. Stratton, J. A., 1941. Electromagnetic Theory. New York: MacGraw Hill.

2. Klein, N., Krause, H.-J., Vitusevich, S., Rongen, H., Kurakin, A., Shaforost, O. N., 2011. Dual-mode microwave cavity for fast identification of liquids in bottles. In: 2011 IEEE MTT-S Int. Microwave Symp. Digest (MTT). Baltimore, USA, 5-10 June 2011, pp. 1-4. DOI: 10.1109/MWSYM.2011.5972696

3. Belozorov, D. P., Girich, A. A., Tarapov, S. I., 2013. An analog of surface Tamm states in periodic structures on the base of microstrip waveguides. [pdf] The Radio Science Bull. 345, pp. 64-72. Available at: http://www.ursi.org/files/RSBissues/ RSB 345 2013 06.pdf

4. Belozorov, D. P., Girich, A. A., Nedukh, S. V., Moskaltsova, A. N., Tarapov, S. I., 2014. Microwave analogue of Tamm states in periodic chain-like structures. Prog. Electromagn. Res. Lett., 46, pp. 7-12. DOI: 10.2528/PIERL13122502

5. Polevoy, S. Y., Vakula, A. S., Nedukh, S. V., Tarapov, S. I., 2017. Fast identification of liquids using planar metamaterial. Telecommunications and Radio Engineering, 76(3), pp. 237243. DOI: 10.1615/TelecomRadEng.v76.i3.40

6. Kozhara, L. I., Polevoy, S. Y., Popov, I. V., 2014. Technique for analysis of the spatial field distribution in tapered wire medium. Solid State Phenom., 214, pp. 75-82. DOI: 10.4028/www.scientific.net/SSP.214.75

Рукопись поступила 10.07.2017.

\section{С. В. Недух, С. Ю. Полевой, С. И. Тарапов,} А. С. Вакула

\section{ИДЕНТИФИКАЦИЯ ЖИДКОСТЕЙ В РАЗЛИЧНЫХ СОСУДАХ С ПОМОЩЬЮ МИКРОВОЛНОВОГО ПЛАНАРНОГО МЕТАМАТЕРИАЛА}

Быстрая бесконтактная идентификации жидкостей, находящихся в сосуде, представляет большой практический интеpec. Данный способ идентификации может применяться, например, в аэропортах, с целью предотвращения провоза в багаже запрещенных жидкостей. Однако применение бесконтактных методов осложняется необходимостью учета влияния характеристик сосуда. В настоящей работе метаматериал на основе двух планарных фотонных кристаллов (ПФК) был применен для экспериментального анализа жидкостей, находящихся в различных сосудах. Экспериментально показано, каким образом изменялся спектр коэффициента пропускания ПФК с изменением характеристик сосуда с жидкостью. Исследовано влияние толщины и материала стенок сосуда, угла наклона его оси относительно плоскости метаматериала на его коэффициент прохождения. Приращение концентрации пищевой соли и сахара в воде при надежном различении растворов было определено как 10 \%. Показано, что увеличение толщины стенки сосуда приводит к снижению надежности идентификации жидкости в нем. Таким образом, было учтено влия- 
ние некоторых характеристик сосуда на надежность бесконтактной идентификации жидкостей с использованием ПФК.

Ключевые слова: метаматериал, фотонный кристалл, идентификация, микроволновый диапазон.

С. В. Недух, С. Ю. Полевой, С. І. Тарапов, А. С. Вакула

\section{ІДЕНТИФІКАЦІЯ РІДИН У РІЗНИХ ПОСУДИНАХ ЗА ДОПОМОГОЮ МІКРОХВИЛЬОВОГО ПЛАНАРНОГО МЕТАМАТЕРІАЛУ}

Швидка безконтактна ідентифікація рідин, що знаходяться в посудинах, становить великий практичний інтерес. Такий спосіб ідентифікації може застосовуватися, наприклад, в аеропортах, 3 метою запобігання провезення у багажі заборо- нених рідин. Однак застосування безконтактних методів ускладнюється необхідністю урахування впливу характеристик посудини. У цій роботі метаматеріал на основі двох планарних фотонних кристалів (ПФК) був застосований для експериментального аналізу рідин, що знаходяться в різних посудинах. Експериментально показано, яким чином змінювався спектр коефіцієнту пропускання ПФК зі зміною характеристик посудини з рідиною. Досліджено вплив товщини і матеріалу стінок посудини, кута нахилу іiі осі відносно площини метаматеріалу на його коефіцієнт проходження. Приріст концентрації харчової солі і цукру у воді за умов надійного розрізнення розчинів було визначено як $10 \%$. Показано, що збільшення товщини стінки посудини призводить до зниження надійності ідентифікації рідини в ній. Таким чином, було враховано вплив деяких характеристик посудини на надійність безконтактної ідентифікації рідин з використанням ПФК.

Ключові слова: метаматеріал, фотонний кристал, ідентифікація, мікрохвильовий діапазон 